\title{
Evaluation of Maternal Serum PAPP-A and hCG Levels at 10-14 Weeks of Gestation in Hyperemesis Gravidarum
}

\section{Hiperemezis Gravidarum Tanısı Alan 10-14 Haftalık Gebelerde Maternal Serum PAAP-A ve hCG Seviyelerinin Değerlendirilmesi}

\author{
๑ Anıl Turhan Çakır, ๑ Ahmet Birtan Boran* \\ Zonguldak Maternity and Child Health Hospital, Clinic of Gynecology and Obstetrics, Oncology Surgery, Zonguldak, Turkey \\ *istanbul Training and Research Hospital, Clinic of Gynecology and Obstetrics, istanbul, Turkey
}

\section{Abstract}

\begin{abstract}
Aim: The aim of this study is to determine the relationship between hyperemesis gravidarum and maternal serum pregnancy-associated plasma protein A (PAPP-A) and human chorionic gonadotropin (hCG) levels. This study was designed as a case-control study.
\end{abstract}

Methods: The study group consists of 54 pregnant women of 10-14 weeks who were diagnosed with hyperemesis gravidarum in the Istanbul Training and Research Hospital Hospital while the control group consists of 54 pregnant women of 10-14 weeks who did not have any complaints. Thyroid stimulating hormone, free T3, free T4, aspartate aminotransferase, alanine aminotransferase, PAPP-A, and hCG values and age were retrospectively scanned from files.

Results: We have observed that the hyperemesis gravidarum group has higher hCG levels as compared with the control group. The mean hCG level in control group and hyperemesis group was $1.10 \pm 0.569$ and $1.55 \pm 1.140$, respectively $(p<0.05)$ The mean PAPP-A level in control group and hyperemesis group was $1.00 \pm 0.611,1.36 \pm 0.887$, respectively $(p<0.05)$.

Conclusion: Elevated levels of PAPP-A and hCG are associated with hyperemesis gravidarum. More comprehensive studies are needed to explain the role of PAPP-A in the pathogenesis of hyperemesis gravidarum.

Keywords: PAPP-A, chorionic gonadotropin, hyperemesis gravidarum
Öz

Amaç: Araştırmamızdaki amacımız hiperemezis gravidarum ile ilk trimester maternal serum hamilelikle ilişkili plazma proteinA (PAPP-A) ve insan koryonik gonadotropin ( $h C G$ ) seviyeleri arasındaki ilişkiyi saptamaktadır. Bu çalışma olgu-kontrol çalışması olarak planlandı.

Yöntemler: Çalışma grubu, İstanbul Eğitim ve Araştırma Hastanesi'nde hiperemezis gravidarum tanısı alan 10-14 haftalık 54 gebeden oluşmaktayken, kontrol grubu ise normal gebelik takibi için polikliniğe başvuran, herhangi bir şikayeti olmayan 10-14 haftalık 54 gebeden oluşmaktadır. Tiroit uyarıc hormon, serbest T3, serbest T4, aspartat aminotransferaz, alanin aminotransferaz, PAPP-A, hCG değerleri ve yaşları retrospektif olarak dosyalardan taranıp karşılaştırıldı.

Bulgular: Çalışma grubundaki gebelerin kontrol grubu ile kıyaslandığında daha yüksek hCG değerlerine sahip olduğu gözlendi. Kontrol grubunda hCG ortalaması 1,10 0 ,569 iken çalışma grubunda $1,55 \pm 1,140$ idi $(p<0.05)$. Kontrol grubunda PAPP-A değerleri ortalaması 1,00 0,611 iken çalışma grubunda $1,36 \pm 0,887$ idi $(p<0.05)$.

Sonuç: Yüksek PAPP-A ve hCG seviyeleri hiperemezis gravidarum ile ilişkilidir. Hiperemezis gravidarum patogenezinde PAPP-A'nın rolünü açıklamak için daha kapsamlı çalışmalara ihtiyaç vardır.

Anahtar Sözcükler: PAPP-A, koryonik gonadotropin, hiperemezis gravidarum
Address for Correspondence/Yazışma Adresi: Anıl Turhan Çakır, Zonguldak Maternity and Child Health Hospital, Clinic of Gynecology and Obstetrics, Oncology Surgery, Zonguldak, Turkey E-mail: dranilturhan@hotmail.com ORCID: orcid.org/0000-0001-7976-4123

Received/Geliş Tarihi: 25 August 2020 Accepted/Kabul Tarihi: 01 November 2020
${ }^{\circ}$ Copyright 2020 by The Medical Bulletin of istanbul Haseki Training and Research Hospital The Medical Bulletin of Haseki published by Galenos Yaynevi. ${ }^{8}$ Telif Hakkı 2020 istanbul Haseki Eğtitim ve Araş̧ırma Hastanesi Haseki Tip Bülteni, Galenos Yayinevi tarafindan yaynlanmış̧tr. 


\section{Introduction}

Nausea and vomiting of pregnancy is seen in approximately $50 \%$ to $80 \%$ of pregnant women in the first trimester of pregnancy and causes negative effects on women's social, professional and family life (1). Hyperemesis gravidarum ( $\mathrm{HG}$ ) can lead to excessive nausea, vomiting, weight loss (around 5\% of body weight) and dehydration, ketosis, electrolyte and acid-base imbalance, sometimes hepatic and renal failure (2).

The etiology of HG has not been clarified. The presence of nausea and vomiting during periods of increased hCG in the blood, an increase in the incidence of HG in multiple pregnancies and gestational trophoblastic diseases shows that hCG may be effective in the etiology (3-5).

Pregnancy-associated plasma protein-A (PAPP-A) was isolated in 1974 as one of the four proteins, placentaderived, found in high concentrations in the blood of pregnant women (6). Although its biological function was unknown for 25 years, it has been used for screening for Down's syndrome (7).

To date, few studies have investigated maternal serum PAPP-A levels in pregnant women with HG. In our study, we aimed to investigate the relationship between $\mathrm{HG}$ and PAPP-A and hCG.

\section{Methods}

This study was approved by the Scientific Research Ethics Committee of İstanbul Training and Research Hospital (approval number-202, date: 16.11.2012) and conducted in compliance with the ethical principles of the Declaration of Helsinki. The study was planned as a retrospective casecontrol study. Patient consent was not obtained because of the retrospective nature of the study. Study group consisted of 54 pregnant women at 10-14 weeks of gestation diagnosed with $\mathrm{HG}$ and the control group consisted of 54 pregnant women at 10-14 weeks of gestation who attended the outpatient clinic for normal pregnancy followup in Istanbul Training and Research Hospital.

Pregnant women with other diseases that may cause vomiting, such as gastritis, nephrolithiasis, cholelithiasis, gastroenteritis, hyperthyroidism and multiple pregnancies, were not included in the study.

Gestational age was determined based on the last menstrual period and ultrasonography measurements. Thyroid stimulating hormone (TSH), free T3 (FT3), free T4 (FT4), aspartate aminotransferase (AST) and alanine aminotransferase (ALT) evalues were obtained from patient files. Pregnancy-associated plasma protein-A (PAPP-A) and human chorionic gonadotropin (hCG) values were achieved from the first trimester prenatal screening test by scanning the records. Plasma levels were expressed with gestational age-specific multiple of median (MoM).
In this study, a special statistical package program was used. Descriptive statistical methods (mean, standard deviation) were used to evaluate the data, as well as the independent samples t-test for comparison of binary groups, and chi-square test for comparison of qualitative data. Significance was evaluated at the level of $p<0.05$.

\section{Results}

The average age of the study and control groups was $27.62 \pm 5.037$ years and $28.33 \pm 5.051$ years, respectively. No statistically significant difference was found in average age between the groups $(p=0.283)$ (Table 1).

The mean AST value in the study and control groups was 16.29 $\pm 5.102 \mathrm{U} / \mathrm{L}$ and $15.35 \pm 6.697 \mathrm{U} / \mathrm{L}$, respectively. The mean ALT value in the study and control groups was $13.99 \pm 7.682 \mathrm{U} / \mathrm{L}$ and $13.17 \pm 13.635 \mathrm{U} / \mathrm{L}$, respectively. No statistically significant difference was found between the two groups ( $p=0.442 p=0.709)$ (Figure 1).

The mean FT3, FT4 and TSH values in the study group were $2.97 \pm 0.945 \mathrm{pg} / \mathrm{mL}, 1.133 \pm 0.328 \mathrm{ng} / \mathrm{dL}$ and $1.248 \pm 1.186 \mathrm{ulU} / \mathrm{mL}$, respectively. The mean FT3, FT4 and TSH values in the control group were $2.99 \pm 0.346 \mathrm{pg} / \mathrm{mL}$, $1.11 \pm 0.140 \mathrm{ng} / \mathrm{dL}$ and $1.68 \pm 1.336 \mathrm{ulU} / \mathrm{mL}$, respectively. No statistically significant difference was found $(p=0.916$, $p=0.803, p=0.087$, respectively) (Figure 2).

It was observed that the pregnant women in the study group had higher hCG values compared to the control group. While the mean hCG value in the control group was $1.10 \pm 0.569$, it was $1.55 \pm 1.140$ in the study group ( $p=0.01)$. Similarly, PAPP-A values were found to be statistically significantly higher in pregnant women in the study group compared to the control group. The mean PAPP-A value in the control group was $1.00 \pm 0.611$ while it was $1.36 \pm 0.887$ in the study group $(p=0.016)$ (Figure 3 ).

Comparison of laboratory values of patient and control groups is shown in Table 2.

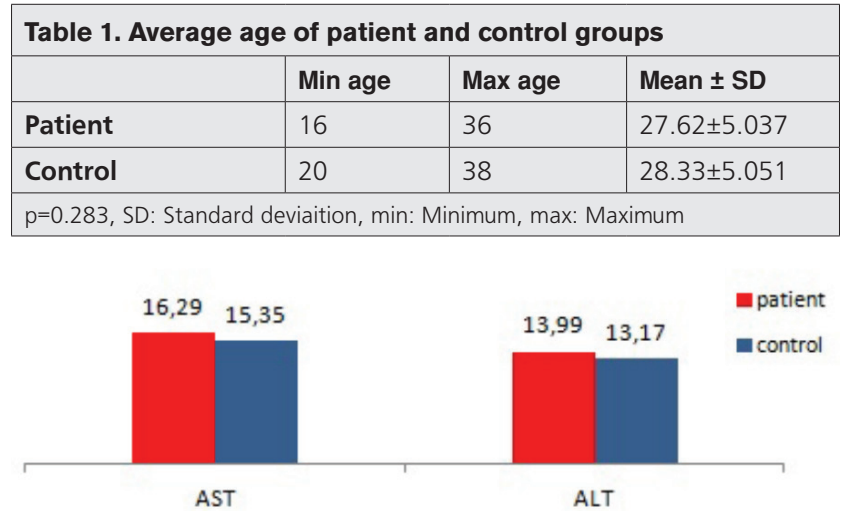

Figure 1. Average of AST and ALT values of patient and control groups

AST: Aspartate aminotransferase, ALT: Alanine aminotransferas 


\section{Discussion}

The etiology of HG has not been clarified. However, hCG is the most likely endocrine factor associated with the development of HG. Presence of nausea and vomiting during periods when hCG peaked in the blood, an increase in the incidence of $\mathrm{HG}$ in multiple pregnancies and gestational trophoblastic diseases supports this theory (3-5).

Burmucic and Weiss (8) compared urine hCG levels in healthy pregnants at the first trimester and patients with $\mathrm{HG}$ in their study. As a result, urinary hCG excretion was found to be $86 \%$ higher in patients with $\mathrm{HG}$.

Goodwin et al. (9) found significantly higher free $\beta$-hCG values in pregnant women with $\mathrm{HG}$ compared to controls.

In their study, Masson et al. (10) divided 116 patients into four group as asymptomatic group, nausea group, nausea + vomiting group and HG group. HCG values were higher in the group with nausea and in the group with nausea + vomiting compared to the asymptomatic group. In the fourth group, HG group, hCG was not higher than in the asymptomatic group.

In their study, Tan et al. (11) argued that hCG affects the severity of HG. They found a relationship between high hCG levels and long hospital stay.

In addition to these studies advocating the relationship between hCG and HG, there are also different studies. In their study, Panesar et al. (12) evaluated thyroid hormones

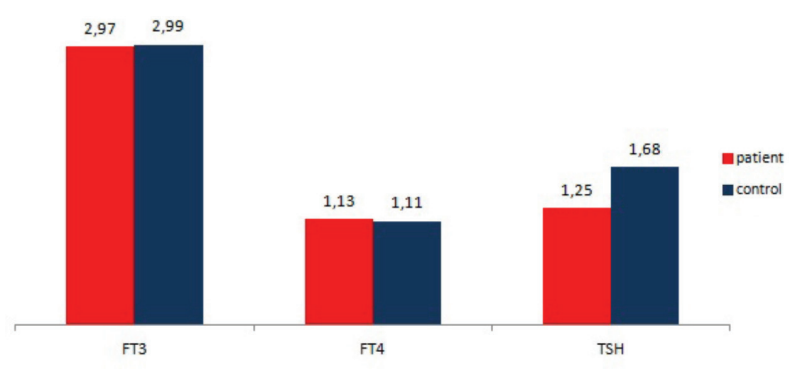

Figure 2. Average of FT3, FT4 and TSH values of patient and control groups

FT3: Free T3, FT4: Free T4, TSH: Thyroid stimulating hormone

\begin{tabular}{|c|c|c|c|}
\hline & Patient (mean \pm SD) & Control (mean \pm SD) & p \\
\hline PAPP-A & $1.36 \pm 0.887$ & $1.00 \pm 0.611$ & 0.016 \\
\hline hCG & $1.55 \pm 1.140$ & $1.10 \pm 0.569$ & 0.010 \\
\hline AST & $16.29 \pm 5.102$ & $15.35 \pm 6.697$ & 0.442 \\
\hline ALT & $13.99 \pm 7.682$ & $13.17 \pm 13.635$ & 0.709 \\
\hline FT3 & $2.97 \pm 0.945$ & $2.99 \pm 0.346$ & 0.916 \\
\hline FT4 & $1.133 \pm 0.328$ & $1.11 \pm 0.140$ & 0.803 \\
\hline TSH & $1.248 \pm 1.186$ & $1.68 \pm 1.336$ & 0.087 \\
\hline \multicolumn{4}{|c|}{$\begin{array}{l}\text { PAPP-A: Pregnancy-associated plasma protein A, hCG: Human chorionic } \\
\text { gonadotropin, AST: Aspartate aminotransferase, ALT: Alanine aminotransferase, FT3: } \\
\text { Free T3, FT4: Free T4, TSH: Thyroid stimulating hormone, SD: Standard deviation }\end{array}$} \\
\hline
\end{tabular}

and hCG in patients with HG and they found high hCG values in HG group. However, after logistic regression analysis, FT4 and TSH were found to be significantly independent variables, while hCG was not found.

Consistent with the majority of the literature, we found higher levels of hCG in the HG group compared to the control group. However, a causal relationship between HG and hCG has not been established in the literature yet.

Increased hCG production in HG can suppress TSH levels by performing a thyrotrophic effect $(13,14)$. Therefore, FT4 and FT3 levels may increase and TSH level may decrease in the first trimester. This is particularly evident in patients with HG. In a systematic review published in 2014, it was found that two thirds of 34 studies reported a decreased TSH level or an increased FT4 level in pregnant women with HG compared to asymptomatic pregnant women. In this review, the authors point out that they were unable to investigate the diagnostic accuracy of thyroid function testing, however, because of the lack of reported cut-off values in the included studies and based on these findings, they recommend thyroid function testing be carried out only to rule out overt thyroid disease among patients with HG but not to diagnose or exclude HG (15).

In our study, no difference was found between the groups in terms of TSH, FT3 and FT4 levels. Although a decrease in TSH levels and an increase in FT4 levels were found in two-thirds of the studies, it was not found in one third. Not every pregnant woman with $\mathrm{HG}$ has to have hyperthyroidism. The reason for not finding a difference in the thyroid profile may be the fact that hCG was not high enough to stimulate the thyroid gland or the patients' thyroid glands were not very sensitive to hCG (16).

In $50 \%$ of patients with $\mathrm{HG}$, one- or two-fold increase in aminotransferases can be detected (17). High transaminases can be induced by disorders in thyroid function (18). Hepatic damage occurs due to relative hypoxia in the perivenular area. Studies have shown that patients with HG having high

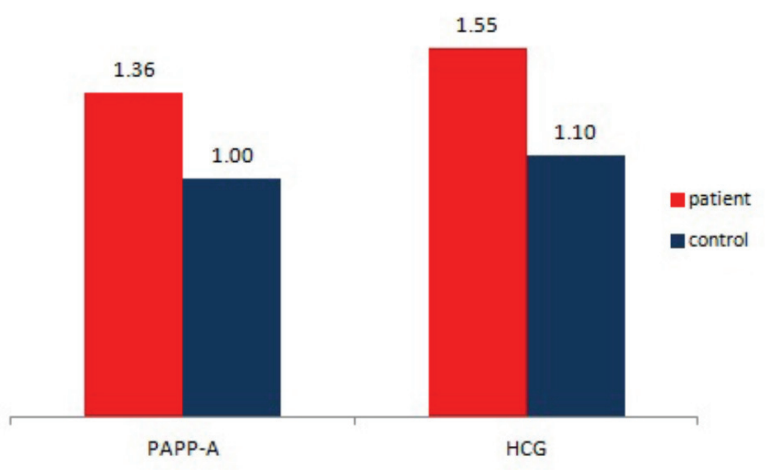

Figure 3. Average of PAPP-A and hCG values of patient and control groups

PAPP-A: Pregnancy-associated plasma protein A, hCG: Human chorionic gonadotropin 
transaminases have low TSH levels and there was a positive relationship between ALT and FT4 (19). In addition, there are studies showing no difference between patients with HG and controls in terms of aminotransferase levels (20). In our study, low TSH levels were not detected in pregnant women with $\mathrm{HG}$, therefore no significant difference was found between the groups in terms of AST and ALT levels.

It has been determined that PAPP-A has protease activity against insulin-like growth factor binding protein-4 (IGFBP-4) $(21,22)$. It needs insulin-like growth factor 1 (IGF1) or IGF-2 to divide IGFBP-4. PAPP-A can be synthesized by vascular smooth muscle cells, ovarian granulosa cells, trophoblasts and many other cells. It is not only a pregnancy-specific protein $(23,24)$. There are studies suggesting that IGFBP protease plays an important role in adjusting local IGF concentration (25). IGFBP-4 has a high affinity for IGF and binds IGF. Thus, it prevents IGF-IGF-1 receptor interaction and inhibits cell growth. Tumor necrosis factor (TNF)- $\alpha$ and interleukin (IL) $1-\beta$ are pro-inflammatory cytokines stimulating the production of PAPP-A in human fibroblasts (26). While PAPP-A production is stimulated by these cytokines, it can be reduced in human fibroblasts pretreated with antioxidant substances such as $\mathrm{N}$-acetyl cysteine. Some of the effects produced by cytokines are associated with oxidative stress.

In a study by Derbent et al. (19), 115 pregnant women with HG and 110 pregnant women without any complaints who participated in the first trimester screening program were compared. Serum PAPP-A and free $\beta$-hCG values were found to be significantly higher in the HG group compared to the control group, and after multivariate analysis, PAPP-A and hCG were independently associated with HG after controlling for TSH, FT4, AST and ALT.

While free $\beta$-hCG, T3, AST, ALT and albumin values did not differ between the groups in a prospective casecontrol study conducted by Unlu et al. (20) including 169 patients hospitalized at least once in the antepartum period due to $H G$, in $H G$ group, serum TSH values were lower and T4 values were significantly higher $(p=0.001)$. PAPP-A values were significantly higher in the HG group than in the control group $(p=0.002)$.

In addition, in a retrospective study conducted by Madendağ et al. (27), fetal nuchal translucency (NT), crown-rump-lenght (CRL), hCG and PAPP-A levels in pregnant women with $\mathrm{HG}$ and healthy pregnants were compared. While both groups were similar in terms of NT, CRL, free $\beta$-hCG values and hCG MoM values, PAPP-A levels were significantly lower in the HG group compared to the control group $(p=0.044)$.

Consistent with most of the few studies examining the relationship between PAPP-A and HG, in our study, PAPP-A levels were found to be significantly higher in the HG group compared to the control group. Although the etiology of HG is not known exactly, it is thought that inflammation plays an important role in the pathogenesis. HG is seen as a result of an overactivated immune system. In recent studies, inflammatory markers were found to be higher in pregnant women with HG compared to healthy pregnant women (28). TNF- $\alpha$ and IL-1b, which are pro-inflammatory cytokines, are the most potent stimulators for PAPP-A and, TNF- $\alpha$ levels have been reported to be high in pregnant women with HG $(20,29)$. The effects of these cytokines can be partially mediated by oxidative stress. Lipid peroxidation and oxidative stress increase due to an increase in free radical activity and deterioration in antioxidant defense system during pregnancy. Low antioxidant enzyme activity and increased oxidative stress have been reported in pregnant women with HG compared to normal pregnant women (30-32). An overactivated immune system and increased oxidative stress and decreased antioxidant activity in HG may cause increased PAPP-A expression (19).

\section{Conclusion}

This study showed that PAPP-A and hCG levels are elevated in the serum of pregnant women with $\mathrm{HG}$ in the first trimester. Although the relationship between hCG and HG has been shown in many studies previously, there are few studies examining the relationship between PAPP-A level and HG. The relationship between PAPP-A and HG has not been clearly elucidated. More comprehensive studies are needed to explain the role of PAPP-A in the pathogenesis of $\mathrm{HG}$.

\section{Authorship Contributions}

Concept: A.T.Ç., A.B.B. Design: A.T.Ç., A.B.B. Data Collection or Processing: A.T.Ç. Analysis or Interpretation: A.T.Ç., A.B.B. Literature Search: A.T.Ç., A.B.B. Writing: A.T.Ç., A.B.B.

Conflict of Interest: No conflict of interest was declared by the authors.

Financial Disclosure: The authors declared that this study received no financial support.

\section{References}

1. Lacroix R, Easton E, Melack R. Nausea and vomiting during pregnancy: a prospective study of its frequency, intensity, and patterns of change. Am J Obstet Gynecol 2000;182:931-7.

2. Fairweather DV. Nausea and vomitingin pregnancy. Am J Obstet Gynecol 1968;102:135-7.

3. Snell LH, Haughey BP, Buck G, Marecki MA. Metabolic Crisis Hyperemesis Gravidarum. J Perinat Neonatal Nurs 1998; 12:26-37.

4. Jarnfelt-Samsoie A. Nause and vomitting in pregnancy: a review. Obstet Gynecol Surv 1987;1:51-60. 
5. Arısan K. Gebelerin Kucuk Şikâyetleri. Propedotik Kadın Doğum, 2. baskı, İstanbul, 1997, Nobel Tıp: 304-5.

6. Lin TM, Halbert SP, Kiefer D, Spellacy WN, Gall S. Characterization of four human pregnancy-associated plasma proteins. Am J Obstet Gynecol 1974;118:223-36.

7. Wald NJ, Watt HC, Hackshaw AK. Integrated screening for Down's syndrome based on tests performed during the first and second trimesters. N Engl J Med 1999;341:461-7.

8. Burmucic R, Weiss PA. Hyperemesis gravidarum and excretion of chorionic gonadotropin in collected 24-hour urine. Geburtshilfe Frauenheilkd 1987;47:111-2.

9. Goodwin TM, Hershman JM, Cole L. Increased concentration of the free beta-subunit of human chorionic gonadotropin in hyperemesis gravidarum. Acta Obstet Gynecol Scand 1994;73:770-2.

10. Masson GM, Anthony F, Chau E. Serum chorionic gonadotrophin (hCG), schwangerschaftsprotein 1 (SP1), progesterone and oestradiol levels in patients with nausea and vomiting in early pregnancy. $\mathrm{Br} J$ Obstet Gynaecol 1985;92:211-21.

11. Tan PC, Tan NC, Omar SZ. Effect of high levels of hCG and estradiol on the severity of hyperemesis gravidarum. Clin Chem Lab Med 2009;47:165-71.

12. Panesar NS, Li CY, Rogers MS. Are thyroid hormones or hCG responsible for hyperemesis gravidarum? A matched paired study in pregnant Chinese women. Acta Obstet Gynecol Scand 2001;80:519-24.

13. Rodien $\mathrm{P}$, Jordan $\mathrm{N}$, Lef'evre $\mathrm{A}$, et al. Abnormal stimulation of the thyrotrophin receptor during gestation. Hum Reprod Update 2004;10:95-105.

14. Goodwin TM, Montoro M, Mestman JH, Pekary AE, Hershman JM. The role of chorionic gonadotropin in transient hyperthyroidism of hyperemesis gravidarum. J Clin Endocrinol Metab 1992;75:1333-7.

15. Niemeijer MN, Grooten IJ, Vos N, et al. Diagnostic markers for hyperemesis gravidarum: a systematic review and metaanalysis. Am J Obstet Gynecol 2014;211:150.e1-15.

16. Kuscu NK, Yildirim Y, Koyuncu F, Var A, Uyanik BS. Interleukin-6 levels in hyperemesis gravidarum. Arch Gynecol Obstet 2003;269:13-5.

17. Kuscu NK, Koyuncu F. Hyperemesis gravidarum: current concepts and management. Postgrad Med J 2002;78:76-9.

18. Kubota S, Amino N, Matsumoto $Y$, et al. Serial changes in liver function tests in patients with thyrotoxicosis induced by Graves' disease and painless thyroiditis. Thyroid 2008;18:2837.

19. Derbent A, Yanık F, Simavli S, et al. First trimester maternal serum PAPP-A and free $\beta$-HCG levels in hyperemesis gravidarum. Prenat Diagn 2011;31:450-3.
20. Unlu BS, Energin H, Yildiz Y, Unlu E, Yapar Eyi EG. Maternal serum pregnancy-associated plasma protein-A levels in hyperemesis gravidarum: a prospective case control study. Clin Exp Obstet Gynecol 2014;41:534-6.

21. Conover CA, Kiefer MC, Zapf J. Posttranslational regulation of insulin-like growth factor binding protein-4 in normal and transformed human fibroblasts: insulin-like growth factor dependence and biological studies. J Clin Invest 1993;91:1129-37.

22. Parker A, Gockerman A, Busby WH, et al. Properties of an insulin-like growth factor-binding protein-4 protease that is secreted by smooth muscle cells. Endocrinology 1995;136:2470-6.

23. Lawrence JB, Oxvig C, Overgaard MT, et al. The insulin-like growth factor (IGF)- dependent IGF binding protein-4 protease secreted by human fibroblasts is pregnancy associated plasma protein-A. Proc. Natl Acad Sci USA 1999;16;96:3149-53.

24. Giudice LC, Conover CA, Balel, et al. Identification and regulation of the IGFBP-4 protease and its physiological inhibitor in human trophoblasts and endometrial stroma: evidence for paracrine regulation of IGF II bioavailability in the placental bed during human implantation. J Clin Endocrinol Metab 2002;87:2359-66.

25. Conover CA, Bale LK, Overgaard MT, et al. Metalloproteinase pregnancy-associated plasma proteinAisa critical growth regulatory factor during fetal development. Development 2004;131:1187-94.

26. Resch ZT, Chen BK, Bale LK, et al. Pregnancy-associated plasma protein A gene expression as a target of inflammatory cytokines. Endocrinology 2004;145:1124-9.

27. Madendağ $Y$, çÖL I, Şahin ME, Şahin E, Açmaz G. Effect of severe hyperemesis gravidarum on PAPP-A and hCG in first trimester. Bozok Med J 2019;9:32-5.

28. Çalışkan CS, Güvey H, Çelik S, Yaşar B, et al. Hiperemezis gravidarum inflamatuar bir süreç mi?. Acta Medica Nicomedia 2020;3:60-5.

29. Laursen LS, Overgaard MT, Weyer K, et al. Cell surface targeting of pregnancy-associated plasma protein $A$ proteolytic activity. Reversible adhesion is mediated by two neighboring short consensus repeats. J Biol Chem 2002 6;277:47225-34.

30. Ustun Y, Engin-Ustun Y, Dokmeci F, Soylemez F. Serum concentrations of lipids and apolipoproteins in normal and hyperemetic pregnancies. J Matern Fetal Neonatal Med 2004;15:287-90.

31. Guney M, Oral B, Mungan T. Serum lipid peroxidation and antioxidant potential levels in hyperemesis gravidarum. Am J Perinatol 2007;24:283-9.

32. Aksoy H, Aksoy AN, Ozkan A, Polat H. Serum lipid profile, oxidative status, and paraoxonase 1 activity in hyperemesis gravidarum. J Clin Lab Anal 2009;23:105-9. 